\title{
The DM and the Ossi Consumer: Price Indexes During Transition
}

\author{
Irwin L. Collier \\ Freie Universität Berlin
}

\begin{abstract}
Family budget data for East and West Germany over the past decade are analyzed in the light of the convergence of relative price structures and the elimination of quantity constraints in the East during the process of eastern economic reconstruction. Exact cost-of-living indexes for generalized CobbDouglas preferences are calculated for the missing (index) link between the end of the old German Democratic Republic and the beginning of German economic unification. Exact deflators are provided for the period 1989 through 1998 for low to high income family budgets.
\end{abstract}

- JEL Classification: D12, P2, C43, E31

- Keywords: Transition Economies, Price Index, Consumer Budgets, Virtual Prices, Demand Systems, East Germany

\section{Introduction}

Had there only been as great an effort to measure the differences in the relative costs of living in East and West Germany following German unification in 1990 as there has been in surveying and analyzing the psychological wall that still divides Wessi from Ossi, this paper would hardly need to have been written. Given the domestic political stakes of a successful economic reconstruction of the East, it may come as a surprise to many readers outside and even inside Germany that

\footnotetext{
*Corresponding address: Irwin Collier; John-F.-Kennedy Institute for North American Studies, Freie Universität Berlin, Lansstr. 7-9, 14195 Berlin, GERMANY. Tel: +49-30-838-53688, E-mail: irwin.collier @fu-berlin.de

C2012-Center for Economic Integration, Sejong Institution, Sejong University, All Rights Reserved.
} 
there has been so little serious empirical work that attempts to quantify the change in living standards in the East across the dividing line of German unification and with only one noteworthy exception has there been any attempt to gauge the difference in price levels between East and West Germany during transition. The purpose of this paper is to demonstrate how one can combine the official economic statistics that are available in a meaningful way to compute price deflators that can be used to unlock the real differences in nominal incomes between East and West Germany as well as between the old and new East Germany. ${ }^{1}$

The methodological trick to extract economic meaning from comparisons of consumer prices between the time of centrally planned socialism and the transition to market capitalism is based upon the obvious fact that the postwar economic history of Germany is the story of twin populations having lived very different economic lives under different systems. The essence of applied demand analysis for market economies is that we allow observed market choices to provide us important information about the structure of the underlying unobserved household preferences. It would be inappropriate, if not folly, to transplant the methods of applied demand analysis for market economies unaltered to the old GDR to try to infer the structure of underlying consumer preferences of East Germans from their observed budget choices. ${ }^{2}$ East Germans before 1990 lived in a world in which there were indeed binding budget constraints but where significant quantity constraints limited household choice as well. That said, if we somehow knew what East German preferences actually were, there would be nothing at all wrong in using that information to interpret the observed choices of German households under central planning. While we can never really "know" the unobserved German preferences, ${ }^{3}$ we can at least try to "estimate" them based upon observed West German choices and then transplant the resulting estimated demand system in order to interpret observed household choices in the East.

In the following section readers will be properly introduced to the underlying

\footnotetext{
'The deflators presented here are used in the companion paper to this one by Beblo, Collier, and Knaus (2012) that examines the distribution of economic gains and losses from unification in East Germany. ${ }^{2}$ This is a deliberate exaggeration since much of the best work in applied demand analysis for market economies is designed to handle realistic deviations from the simplest case of a linear budget constraint and interior solutions. What is meant here is that household choice sets were much more complex under centrally planned socialism (or at least very different) and the other constraints faced by households are far less well documented in a statistical sense so that there is little hope in untangling the various constraints and estimating the underlying preferences simultaneously.

${ }^{3}$ It is hard to imagine a situation where the assumption of identical preferences would be more appropriate than for the case of divided Germany.
} 
price and budget data upon which the deflators of this paper are built. This brief encounter with the data will be followed by an outline of the generalized CobbDouglas specification for consumer preferences that has been fitted to West German price and budget data and that will serve as the engine of the analysis of prices and household budgets in East Germany over the period 1989-1998. To obtain the exact deflators that are the principal motivation of this paper, we will need to compute Rothbarthian virtual prices ${ }^{4}$ along with the level of utility associated with observed East German quantities. The calculation of exact deflators in order to convert observed East German nominal expenditure into the minimum expenditure required to achieve East German utility for an arbitrary base year of West German DM prices may seem almost anticlimactic, but providing deflators ready to use and useful for empirical research is certainly not the worst way to end a paper.

\section{Data}

Official consumer price indexes published by the Federal Statistical Office of Germany are readily available for the country as a whole and separately for the new (East) and the old (West) federal states beginning in 1981 for the West and 1991 for the East. ${ }^{5}$ These consumer price indexes aggregated to the sixteen categories of expenditure used in this paper have been assembled for the most part by a straight-forward chaining of the corresponding indexes. ${ }^{6}$ With some modest additional effort and knowing where to look, East German indexes for detailed expenditure categories can be even backcast to 1989, the year preceding German unification. $^{7}$ All sixteen category price indexes in East and West are set equal to unity for 1991 initially. Thus from the chained published price index data alone we are only able to observe the parallel development of consumer prices in East and West. The missing ingredient to calculate the purchasing power of the DM in East

\footnotetext{
${ }^{4}$ Virtual prices were the brainchild of Erwin Rothbarth who analyzed British wartime rationing in a classic article (Rothbarth (1941)). Virtual prices are defined to be the set of prices that would induce a solely budget constrained household to freely choose the effective demands when both budget and quantity constraints are binding. Virtual prices were brought back into vogue by Neary and Roberts (1980).

${ }^{5}$ Statistisches Bundesamt (1984-1998): Preise und Preisindizes für die Lebenshaltung. Fachserie 17. Reihe 7. ${ }^{6}$ The West German time series are partially overlapping with respect to the base years 1980, 1985, 1991, and 1995. The East German time series are partially overlapping with respect to the base years July, 1990-June, 1991, and 1995

${ }^{7}$ See Appendix A and the sources cited therein.
} 
and West are detailed price comparisons. With the exception of a single comparison of consumer prices in fifty German localities in $1993,{ }^{8}$ there really has been no serious attempt to gauge the difference of the cost of living between the old and new states of Germany. Fortunately these data (the first column in Table 1) are quite adequate to serve as an East-West bridge for the price levels in 1993 which are then forecast and backcast using the chained series previously described, fixing the 1991 West German level at unity (see the second and third columns in Table 1 for the year 1993).

Table 1. Bridges between 1993 East and West German price levels

\begin{tabular}{lccc}
\hline & $P_{E}^{93} / P_{W}^{93}$ & $P_{W}^{93} / P_{W}^{91}$ & $P_{E}^{93} / P_{W}^{91}$ \\
& $(1)$ & $(2)$ & $(3)$ \\
\hline Food & 0.900 & 1.031 & 0.9278 \\
Beverages & 0.982 & 1.062 & 1.0432 \\
Tobacco & 1.000 & 1.111 & 1.1110 \\
Public dining & 0.893 & 1.090 & 0.9734 \\
& & & \\
Clothing and footwear & 0.986 & 1.059 & 1.0442 \\
Rent & 0.650 & 1.116 & 0.7254 \\
Fuel and power & 0.928 & 1.020 & 0.9462 \\
Furniture, furnishings, household equipment & 0.956 & 1.062 & 1.0149 \\
and operations & & & \\
& & & \\
Health and personal care & 0.864 & 1.062 & 0.9172 \\
Personal transport equipment & 1.004 & 1.094 & 1.0988 \\
Operation of personal transport equipment & 0.937 & 1.089 & 1.0207 \\
Purchased transport services & 0.712 & 1.086 & 0.7732 \\
& & & \\
Communications & 1.000 & 1.036 & 1.0360 \\
Radio, television sets, phonographs & 1.000 & 0.974 & 0.9740 \\
Recreation, entertainment, education, n.e.c. & 0.920 & 1.080 & 0.9941 \\
Personal effects, travel & 0.953 & 1.139 & 1.0852 \\
\hline Source & & & \\
\hline
\end{tabular}

Source:

Col (1). See the description of the data set in Ströhl, G. (1994).

Col (2): Consumer price index, west German states

Col (3): Col (1) multiplied by $\mathrm{Col}(2)$.

${ }^{8}$ The survey is described in Ströhl (1994). Mr. Ströhl graciously provided disaggregated data that made the East/West price bridges for these sixteen categories possible. 
Table 2. Purchasing power of the GDR-Mark (1989) and of the DM in East Germany (1998) expressed in DM at current West German prices, average annual price changes by expenditure category

\begin{tabular}{|c|c|c|c|c|}
\hline & $\begin{array}{l}\text { PPP } \\
1989\end{array}$ & $\begin{array}{l}\text { Avg. Annual } \\
\text { Price Change }\end{array}$ & $\begin{array}{l}\text { Avg. Annual } \\
\text { Price Change } \\
\text { West }\end{array}$ & $\begin{array}{l}\text { PPP } \\
1998\end{array}$ \\
\hline Rent & 8.50 & $27.1 \%$ & $3.9 \%$ & 1.38 \\
\hline Purchased transport services & 3.82 & $18.5 \%$ & $3.1 \%$ & 1.09 \\
\hline Fuel and power & 3.50 & $14.7 \%$ & $1.0 \%$ & 1.11 \\
\hline Communications & 2.74 & $13.8 \%$ & $0.9 \%$ & 0.92 \\
\hline Public dining & 2.53 & $12.7 \%$ & $2.6 \%$ & 1.08 \\
\hline Health and personal care & 1.85 & $9.5 \%$ & $2.9 \%$ & 1.05 \\
\hline $\begin{array}{l}\text { Recreation, entertainment, education, } \\
\text { n.e.c. }\end{array}$ & 1.49 & $7.3 \%$ & $2.5 \%$ & 0.99 \\
\hline Personal effects, travel & 1.41 & $7.3 \%$ & $3.4 \%$ & 1.01 \\
\hline Food & 1.28 & $3.4 \%$ & $1.8 \%$ & 1.12 \\
\hline Tobacco & 0.98 & $2.6 \%$ & $2.9 \%$ & 1.00 \\
\hline $\begin{array}{l}\text { Operation of personal transport equip- } \\
\text { ment }\end{array}$ & 0.90 & $1.3 \%$ & $3.6 \%$ & 1.11 \\
\hline $\begin{array}{l}\text { Furniture, furnishings, household } \\
\text { equipment and operations }\end{array}$ & 0.81 & $-1.3 \%$ & $1.9 \%$ & 1.08 \\
\hline Clothing and footwear & 0.66 & $-3.5 \%$ & $1.6 \%$ & 1.05 \\
\hline Beverages & 0.51 & $-6.3 \%$ & $1.7 \%$ & 1.05 \\
\hline Personal transport equipment & 0.46 & $-6.6 \%$ & $2.0 \%$ & 1.01 \\
\hline Radio, television sets, phonographs & 0.34 & $-13.0 \%$ & $-1.5 \%$ & 1.03 \\
\hline
\end{tabular}

The price data are summarized in the four columns of Table 2. The expenditure categories have been ordered according to the purchasing power of the GDR mark in each category in 1989. The range extends from one GDR mark in East Germany purchasing as much housing as $8.5 \mathrm{DM}$ in West Germany, down to a purchasing power of one-third DM with regard to the category radio, TV, and phonographs. The last column in Table 2 shows the remarkable convergence of the purchasing power parities within a decade, with housing continuing to constitute the major outlier. This convergence is achieved by dramatic increases and decreases in consumer prices in East Germany compared to the relatively tight range of price changes in the West (compare the second and third columns of Table 2).

The observed consumer choices referred to in the introduction are found in household budget surveys for three distinct household types. The West German 
expenditure data ${ }^{9}$ are available according to a consistent classification system for the period 1981-1998 and for East Germany since 1989. ${ }^{10}$ Thus the time series of annual average family budgets for East and West Germany for retired two adult households (Type 1) and working middle-income/high-income four person (two adults/two children) households (Type 2 and Type 3, respectively) are reasonably consistent both across time and space. Implicit quantities for all households and all years are calculated by deriving the category price indexes described above into the nominal category expenditures from the family budgets and thus are measured in the units of "monthly spending in DM valued at 1991 West German prices."

\section{Specification of Household Preferences}

The specification used to calculate exact deflators is a generalization of the Cobb-Douglas demand system ${ }^{11}$ that permits budget shares to vary systematically with real income. As in the simple Cobb-Douglas specification, the compensated price elasticity of each good is minus unity. The point of this generalization is that income elasticities are not constrained to be equal to unity which is most desirable because West German data are clearly consistent with Engel's Law, i.e., budget shares do indeed vary systematically with increasing real budgets. We are well advised to respect Engel's Law because our East German observations (for which we need to forecast out-of-sample) are significantly below West German average levels.

The geometric intuition behind the generalization of Cobb-Douglas preferences used here comes from the fact that in log-quantity space, simple (i.e., constant expenditure share) Cobb-Douglas preferences would be represented as a family of parallel indifference planes, the slopes of which being a function of the budget shares. The point of the generalization is to allow the indifference planes in log quantity space to "fan out" with increasing income so that budget shares can vary systematically with changing real income.

\footnotetext{
${ }^{9}$ Statistisches Bundesamt. (1984-1998). Einnahmen und Ausgaben ausgewählter privater Haushalte. Fachserie 15. Reihe 1.

${ }^{10}$ The Eastern German family budget surveys for 1989 as well as for the first and second halves of 1990 based upon GDR budget classifications were re-aggregated to conform to the West German classification system by a team of former GDR statisticians working for the Federal Statistical Office, Statistisches Bundesamt (1993). For 1991-98 the East German family budget data are taken from the publication cited in the previous footnote.

${ }^{11}$ For other applications of the generalized Cobb-Douglas demand system used here, see Collier (1986, 1989, 2005).
} 
We begin with the indirect utility function that expresses the maximum level of utility achievable by a household in a market economy, i.e., subject solely to a budget constraint $(y)$, conditional on that budget constraint and conditional on the prices of goods it faces (expressed as a vector $\mathbf{p}$ ):

$$
v\left(\mathbf{p}_{i}, y_{i}\right)=\prod_{k=1}^{K}\left(y_{i} / p_{k i}\right)^{\beta_{k i}}=y_{i} / \prod_{k=1}^{K}\left(p_{k i}\right)^{\beta_{k i}}
$$

where $i(=E, W)$ denotes Eastern or Western Germany and $k(=1, \ldots, K)$ denotes the sixteen categories of expenditure. ${ }^{12}$ The second equality in equation (1) is due to the fact that the budget shares $\left(\beta_{k}\right)$ sum to unity in any period. We transform equation (1) into log-form and obtain

$$
\ln v_{i}=\ln y_{i}-\sum_{k} \beta_{i k} \ln p_{i k} .
$$

So that these preferences are indeed consistent with Engel's law we explicitly let the budget shares vary systematically with real income (indirect utility) itself.

$$
\beta_{k i}=\frac{\alpha_{k} v_{i}^{\gamma_{k}}}{\sum_{m=1}^{K} \alpha_{m} v_{i}^{\gamma_{m}}}
$$

where the $\alpha_{k}$ would in fact be proportional to the budget shares $\left(\beta_{k}\right)$ were these not to differ in their response $\left(\gamma_{k}\right)$ with respect to real income (which itself is hidden in the indirect utility which is $v$ ) from the responses $\left(\gamma_{m}\right)$ of other goods. To eliminate the denominator we choose a reference category, $n$ (here food), and drop the East/ West subscript ( $i$ ) for convenience

$$
\frac{\beta_{k}}{\beta_{n}}=\frac{\alpha_{k} v^{\gamma_{k}}}{\alpha_{n} v^{\gamma_{n}}}=\left(\frac{\alpha_{k}}{\alpha_{n}}\right) v^{\left(\gamma_{k}-\gamma_{n}\right)} .
$$

The log-form of equation (4) provides us an estimation equation:

$$
\ln \left(\beta_{k} / \beta_{n}\right)=\ln \left(\alpha_{k} / \alpha_{n}\right)+\left(\gamma_{k}-\gamma_{n}\right) \ln v=\tilde{\alpha}_{k}+\tilde{\gamma}_{k} \ln v
$$

\footnotetext{
${ }^{12}$ In the interest of avoiding yet another subscript to denote historical time, the reader should note that in these specification prices (p), budget constraint $(y)$ and the budget shares $\left(\beta_{k}\right)$ can all vary. By force of habit some readers might mistakenly regard the budget shares as constants which would only be true for a traditional Cobb-Douglas world which is of course just one particular case of the Generalized CobbDouglas specification
} 
where the log indirect utility on the right hand side of equation (5) can be calculated with observed prices, total budget and budget shares using equation (2). ${ }^{13}$ Given an arbitrary $v$, we have $(K-1)$ linear forecasting equations of the log of budget share ratios. The $K^{\text {th }}$ equation that allows us to forecast all $K$ budget shares for an arbitrary $v$ is obtained from the condition that the budget shares must sum to unity.

\section{Estimation}

Separate demand systems are estimated using annual observations of average monthly expenditures for (i) two-adult households (predominantly elderly) whose principal source of income is public pensions and/or public assistance and (ii) two adult, two children households. The OLS regression coefficients and their estimated standard errors are reported for both household types in Table 3.

The missing category of expenditure is the $n^{\text {th }}$ good (food) in the regressions. ${ }^{14}$ The observations for high and middle income working households of two adults and two children have been pooled which is undoubtedly the reason for the generally better performance of the regressions in Table 3(b) than for the elderly 2person households in Table 3(a) for whom the real income variation is limited to that over the time period examined.

The low $R^{2}$ of some of the regressions (e.g., beverages, fuel, and power and rent) is not cause for alarm. With sixteen categories of spending we can of course expect some groups of goods to have similar income elasticities. Some budget shares would naturally move parallel to that of food as real income changes so that real income changes will not be a useful predictor of the difference in the size of those budget shares. Of course were all of the budget shares to move with food, then none of the budget shares could ever change, i.e., we would have the special case of a traditional Cobb-Douglas specification. Examination of the $R^{2}$ (or the standard errors of the slope parameters $\left[\gamma_{k}-\gamma_{n}\right]$ ) shows that this is indeed not the case in the West German household budget data. In Ernst Engel we trust and the data indeed reveal that, with the exception of tobacco expenditure, there is hardly an instance

\footnotetext{
${ }^{13}$ Statistically sensitive readers might be offended by the fact that the "independent" variable on the right hand side of (5) is in fact dependent in a nonlinear way on the budget shares found on the left hand side. An obvious instrument to use is an unweighted price index instead of the weighted price index on the right hand side of (2) or a fixed weighted price index with the weights taken from another country.

${ }^{14}$ It does not matter which of the sixteen expenditure groups is used in the capacity of the $n^{\text {th }}$ good. The same budget shares will indeed be forecast for the same prices and total budget.
} 
Table 3a. OLS estimates of generalized Cobb Douglas coefficients. West German Type 1 households, 1981-98.

\begin{tabular}{|c|c|c|c|}
\hline & $\operatorname{In}\left(\alpha_{i}-\alpha_{n}\right)$ & $\left(\gamma_{i}-\gamma_{n}\right)$ & $R^{2}$ \\
\hline Beverages & $\begin{array}{c}-3.222 \\
(0.998)\end{array}$ & $\begin{array}{c}0.218 \\
(0.133)\end{array}$ & 0.144 \\
\hline Tobacco & $\begin{array}{l}9.668 \\
(2.323)\end{array}$ & $\begin{array}{l}-1.705 \\
(0.310)\end{array}$ & 0.654 \\
\hline Public dining & $\begin{array}{r}-17.610 \\
(1.828)\end{array}$ & $\begin{array}{c}2.104 \\
(0.244)\end{array}$ & 0.823 \\
\hline Clothing and footwear & $\begin{array}{l}-5.406 \\
(0.889)\end{array}$ & $\begin{array}{c}0.547 \\
(0.119)\end{array}$ & 0.571 \\
\hline Rent & $\begin{array}{c}-17.889 \\
(1.878)\end{array}$ & $\begin{array}{c}2.427 \\
(0.251)\end{array}$ & 0.854 \\
\hline Fuel and power & $\begin{array}{l}-1.668 \\
(1.090)\end{array}$ & $\begin{array}{c}0.106 \\
(0.146)\end{array}$ & 0.032 \\
\hline Furniture, furnishings, household equipment and operations & $\begin{array}{l}-7.533 \\
(1.916)\end{array}$ & $\begin{array}{c}0.857 \\
(0.256)\end{array}$ & 0.412 \\
\hline Health and personal care & $\begin{array}{c}-17.595 \\
(2.038)\end{array}$ & $\begin{array}{c}2.164 \\
(0.272)\end{array}$ & 0.798 \\
\hline Personal transport equipment & $\begin{array}{r}-64.807 \\
(6.871)\end{array}$ & $\begin{array}{c}8.345 \\
(0.917)\end{array}$ & 0.838 \\
\hline Operation of personal transport equipment & $\begin{array}{l}-31.081 \\
(1.978)\end{array}$ & $\begin{array}{c}3.921 \\
(0.264)\end{array}$ & 0.932 \\
\hline Purchased transport services & $\begin{array}{c}4.551 \\
(1.838)\end{array}$ & $\begin{array}{l}-0.955 \\
(0.245)\end{array}$ & 0.487 \\
\hline Communications & $\begin{array}{l}-9.574 \\
(0.768)\end{array}$ & $\begin{array}{c}1.011 \\
(0.103)\end{array}$ & 0.859 \\
\hline Radio, television sets, phonographs & $\begin{array}{c}-15.002 \\
(4.430)\end{array}$ & $\begin{array}{c}1.557 \\
(0.591)\end{array}$ & 0.302 \\
\hline Recreation, entertainment, education, n.e.c. & $\begin{array}{r}-15.337 \\
(0.837)\end{array}$ & $\begin{array}{c}1.880 \\
(0.112)\end{array}$ & 0.946 \\
\hline Personal effects, travel & $\begin{array}{c}-13.281 \\
(1.391)\end{array}$ & $\begin{array}{c}1.539 \\
(0.186)\end{array}$ & 0.811 \\
\hline
\end{tabular}

Note: Low income, predominantly elderly couples with primary income from pension or public assistance (Type 1). Annual averages, 1981-1998 for a total of 18 observations. 
Table 3b. OLS estimates of generalized Cobb Douglas coefficients. West German Type 2 and Type 3 households, 1981-98.

\begin{tabular}{|c|c|c|c|}
\hline & $\ln \left(\alpha_{i}-\alpha_{n}\right)$ & $\left(\gamma_{i}-\gamma_{n}\right)$ & $R^{2}$ \\
\hline Beverages & $\begin{array}{l}-2.184 \\
(0.297)\end{array}$ & $\begin{array}{c}0.088 \\
(0.035)\end{array}$ & 0.154 \\
\hline Tobacco & $\begin{array}{c}8.860 \\
(0.633)\end{array}$ & $\begin{array}{l}-1.453 \\
(0.076)\end{array}$ & 0.915 \\
\hline Public dining & $\begin{array}{l}-8.888 \\
(0.307)\end{array}$ & $\begin{array}{c}0.904 \\
(0.037)\end{array}$ & 0.947 \\
\hline Clothing and footwear & $\begin{array}{l}-5.805 \\
(0.478)\end{array}$ & $\begin{array}{c}0.626 \\
(0.057)\end{array}$ & 0.779 \\
\hline Rent & $\begin{array}{l}-4.162 \\
(1.246)\end{array}$ & $\begin{array}{c}0.539 \\
(0.149)\end{array}$ & 0.278 \\
\hline Fuel and power & $\begin{array}{l}-0.754 \\
(0.589)\end{array}$ & $\begin{array}{l}-0.029 \\
(0.070)\end{array}$ & 0.005 \\
\hline $\begin{array}{l}\text { Furniture, furnishings, household equipment and opera- } \\
\text { tions }\end{array}$ & $\begin{array}{l}-5.677 \\
(0.460)\end{array}$ & $\begin{array}{c}0.608 \\
(0.055)\end{array}$ & 0.782 \\
\hline Health and personal care & $\begin{array}{l}-19.138 \\
(0.562)\end{array}$ & $\begin{array}{c}2.158 \\
(0.067)\end{array}$ & 0.968 \\
\hline Personal transport equipment & $\begin{array}{l}-7.130 \\
(1.324)\end{array}$ & $\begin{array}{c}0.766 \\
(0.158)\end{array}$ & 0.408 \\
\hline Operation of personal transport equipment & $\begin{array}{l}-5.322 \\
(0.584)\end{array}$ & $\begin{array}{c}0.546 \\
(0.070)\end{array}$ & 0.642 \\
\hline Purchased transport services & $\begin{array}{l}-12.775 \\
(1.132)\end{array}$ & $\begin{array}{c}1.234 \\
(0.135)\end{array}$ & 0.710 \\
\hline Communications & $\begin{array}{l}-5.075 \\
(0.469)\end{array}$ & $\begin{array}{c}0.356 \\
(0.056)\end{array}$ & 0.542 \\
\hline Radio, television sets, phonographs & $\begin{array}{l}-6.868 \\
(0.773)\end{array}$ & $\begin{array}{c}0.531 \\
(0.092)\end{array}$ & 0.492 \\
\hline Recreation, entertainment, education, n.e.c. & $\begin{array}{l}-7.890 \\
(0.825)\end{array}$ & $\begin{array}{c}0.900 \\
(0.099)\end{array}$ & 0.710 \\
\hline Personal effects, travel & $\begin{array}{r}-10.712 \\
(0.702)\end{array}$ & $\begin{array}{c}1.140 \\
(0.084)\end{array}$ & 0.844 \\
\hline
\end{tabular}

Note: Households of two-adults, 2 children, middle and higher income pooled (Type 2 and Type 3, respectively). Annual averages, 1981-1998 for a total of 36 observations. 
of a significant negative slope coefficient (public transportation for the elderly households appears to be the only other genuine exception) so that the food income elasticity is in almost all cases smaller than for other categories of expenditure.

Before transplanting the estimated West German parameters into East German reality, it is worth to give a brief look at the in-sample plots presented in Figure 1. Observed quantities are plotted as individual points and fitted values are plotted as a line for each of the categories of expenditure for different household types (all three wherever clarity permits). While the points and lines clearly fit together, they are not always a perfect fit and indeed there are a few curious misfits. It does appear that it is the variation of budgets between the middle and higher income household types that drives the fitted values for the pooled working households. The quantity of housing can be seen to be increasing for both household types over time but such a trend is not seen in the fitted values. Wrong in a different sense are the fitted values for shoes and clothing that show upward trends that are not really seen in the observed quantities. In spite or because of these empirical curiosities it is worth reminding ourselves that the use of this demand system will be to interpret household behavior at a significantly lower level of real income. On this important score it is at least reassuring to see that the fitted values for the higher and middle income households are near the observed values.

\section{Stepping out of Sample}

Since the proof of this demand system will lie on whether or not it helps us interpret household consumption patterns in the East, we turn to the 48 panels of Figures 2-4 showing sixteen categories of consumer demand in East Germany for each of the three household types, this time keeping middle and high income working four person households distinct from each other. It should hardly surprise us to find that a demand system estimated for solely budget-constrained consumers in the West does not predict at all well for a system in which households are both budget and quantity constrained. We do have a right to expect, however, if there is anything to the assumption of identical preferences for East and West Germans, that the quality of the fit should improve as economic transition proceeds.

For each of the sixteen categories it is interesting to inspect the 1989 observation, which is a relatively pure GDR observation. There we see patterns of excess demand and spillover consumption that one expects, e.g., the enormous notional demand for housing (rents) compared to the observed effective demand 
Figure 1a. Observed and fitted demands, West Germany (DM per month, 1991 West German prices)

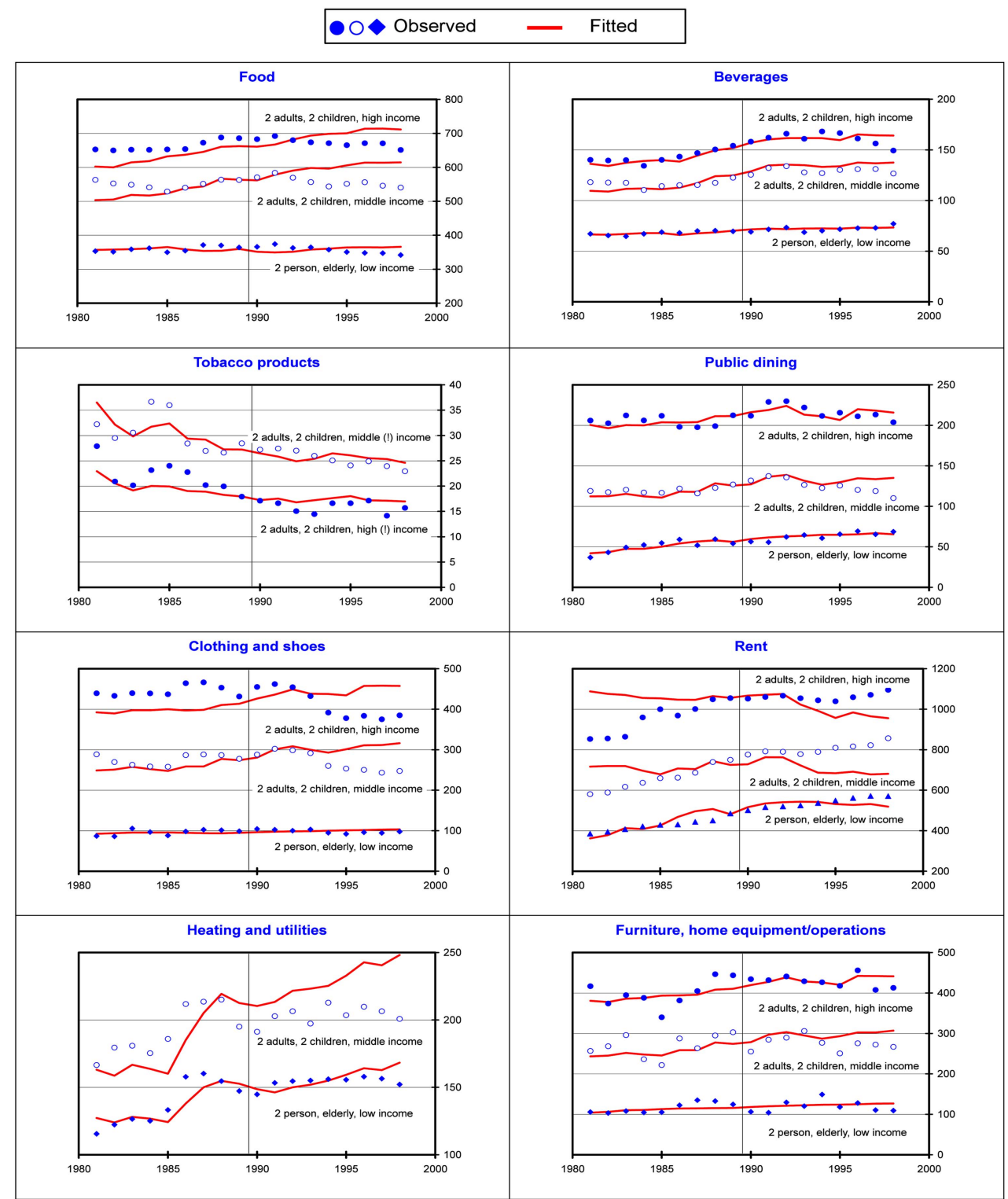

for housing and the relatively high spillover of expenditure into restaurants and pubs (public dining).

At first glance one might be somewhat surprised by the relatively close correspondence between notional and effective demand for automobiles and 
Figure 1b. Observed and fitted demands, West Germany (DM per month, 1991 West German prices)

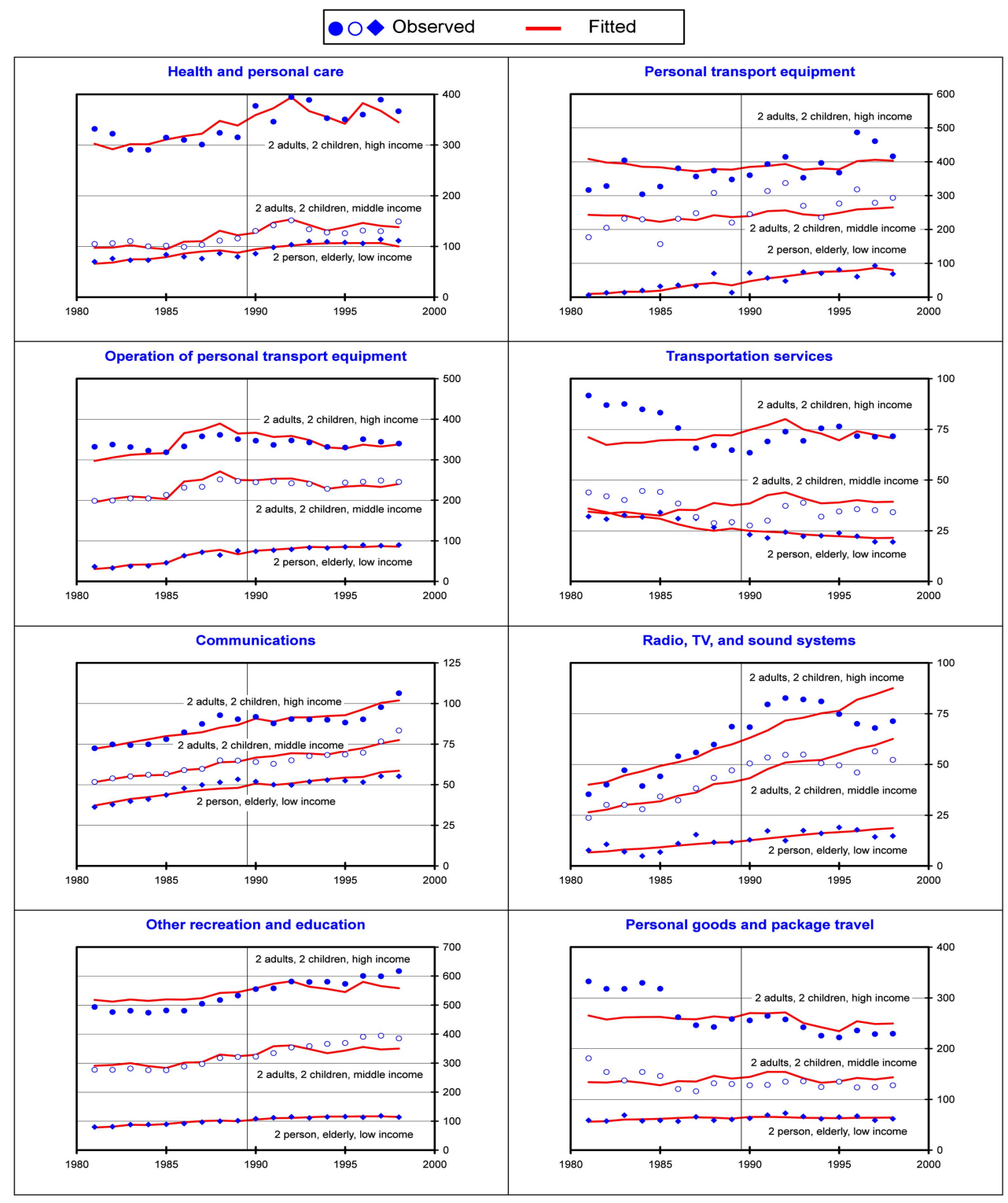

bicycles (personal transport equipment) for 1989. One needs to keep in mind that for the relatively expensive prices of automobiles and the genuinely cheap housing rents, the estimated demand system is telling us nothing more than an East German family with no quantity constraints for housing or automobiles (or anything else) 
Figure 2a. Observed and predicted demands, Type 1 households, East Germany (DM per month, 1991 West German prices)

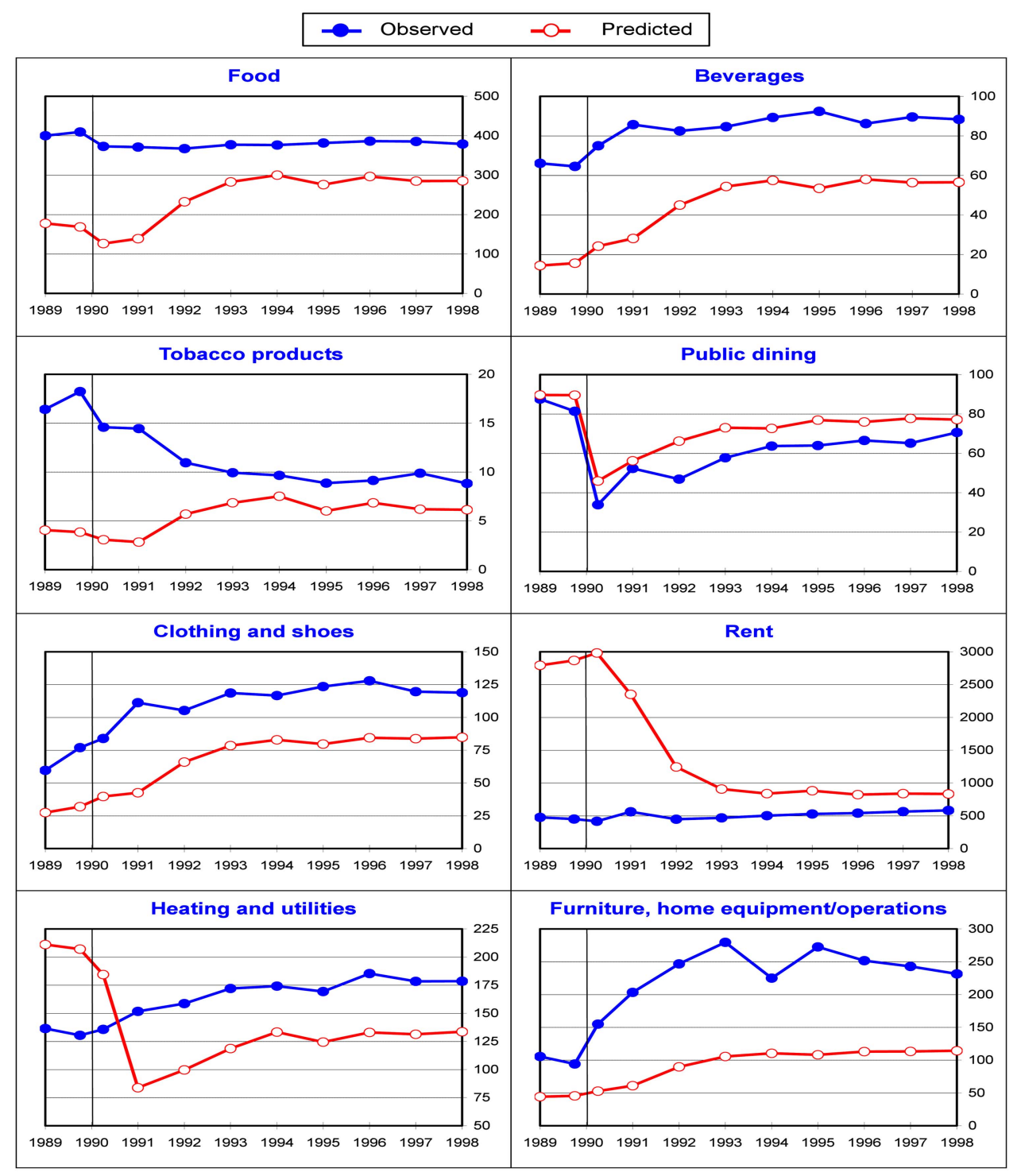

would have spent an awful lot for the family villa and would have had relatively little disposable income left over for their cars. (In real terms we are still talking about double the quantity of "personal transport equipment" being demanded!)

Besides this retrospective glimpse to the quantity-constrained world of the GDR, the 48 panels of Figures 2-4 together tell an overwhelming story of the 
Figure 2b. Observed and predicted demands, Type 1 households, East Germany (DM per month, 1991 West German prices)

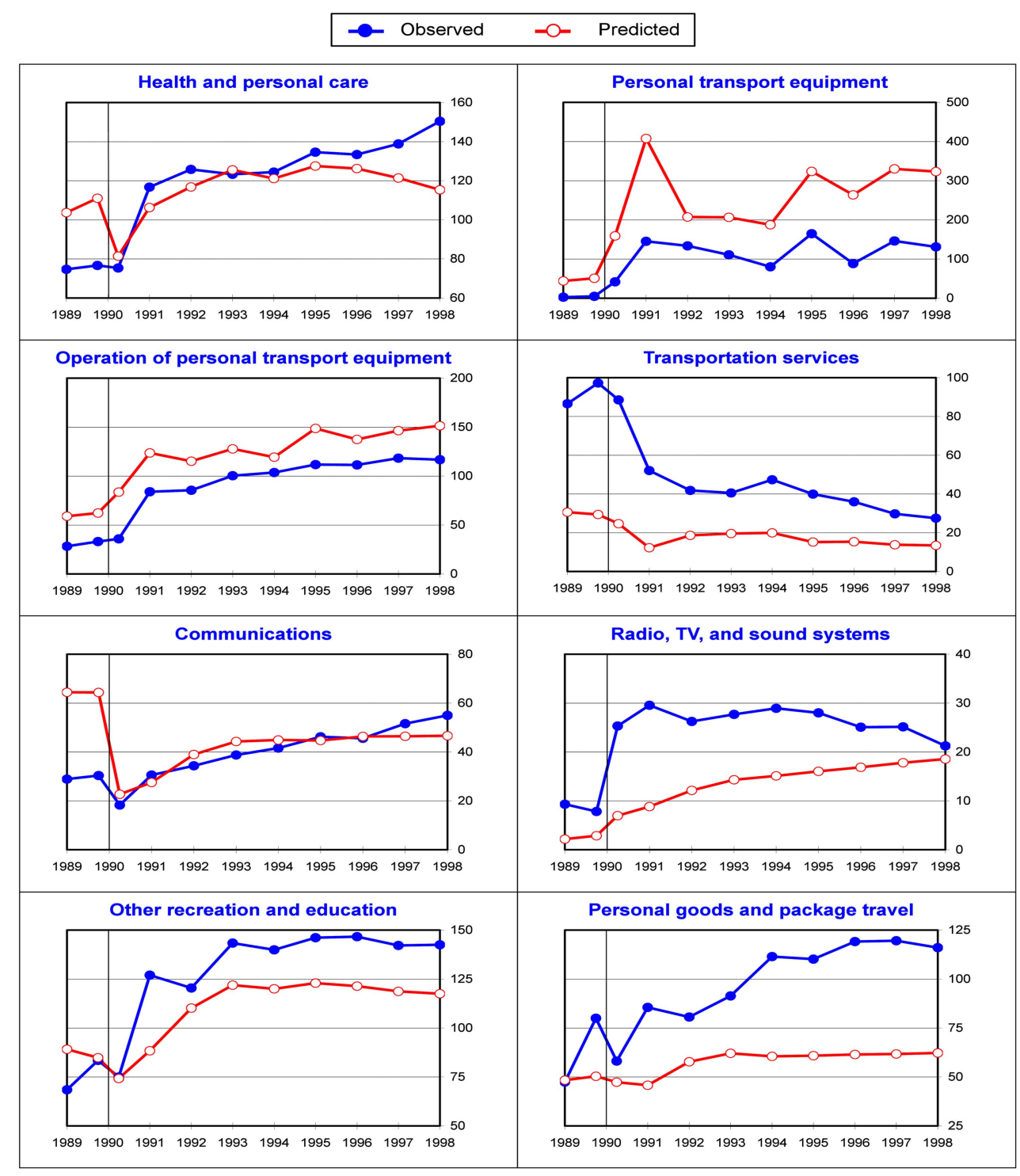

convergence of East German consumption to West German patterns. By the end of the period investigated one sees that predicted quantities associated with the observed prices and budgets in the new states have come closer to actual consumption in about 13 of the spending categories compared to the start of eastern German economic reconstruction. 
For some categories of expenditure the convergence of observed quantities to those predicted from the West German demand system (e.g., beverages, tobacco products, rent, communications) is genuinely striking. For other categories, the initial postwall surge in spending (e.g. cars, radios, television sets, sound systems) is followed by a gradual return to normality as captured in the predicted consumption patterns toward the end of the period.

Figure 3a. Observed and predicted demands, Type 2 households, East Germany (DM per month, 1991 West German prices

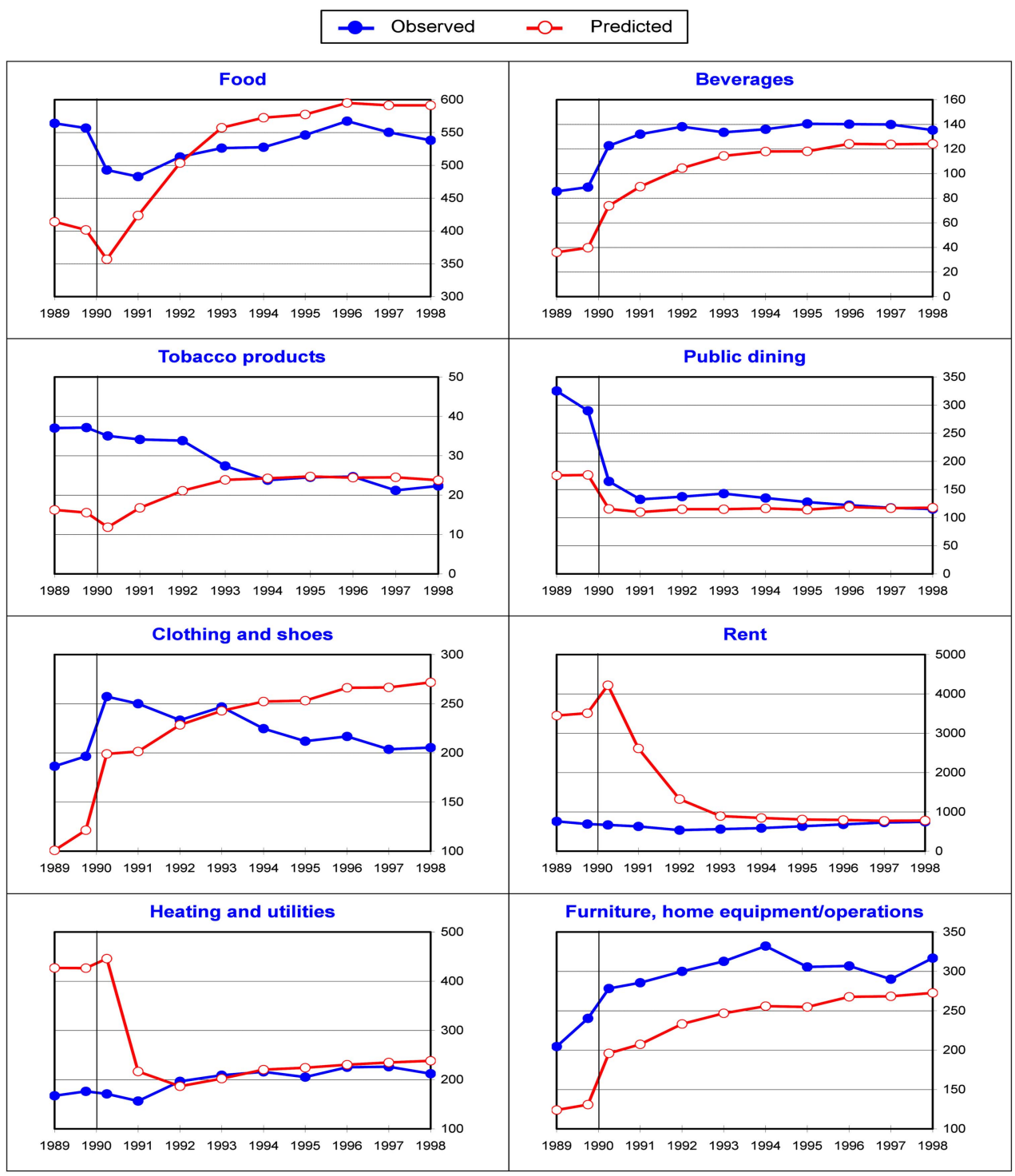


The abundance of detail presented for sixteen categories of household spending for three types of households over a period of a decade as presented in Figures 2-4 is fascinating but overwhelming. Most readers by now will have developed a craving for a few good numbers that summarize what we think we just might have seen: a convergence of forecast values to observations over the course of the

Figure 3b. Observed and predicted demands, Type 2 households, East Germany (DM per month, 1991 West German prices)

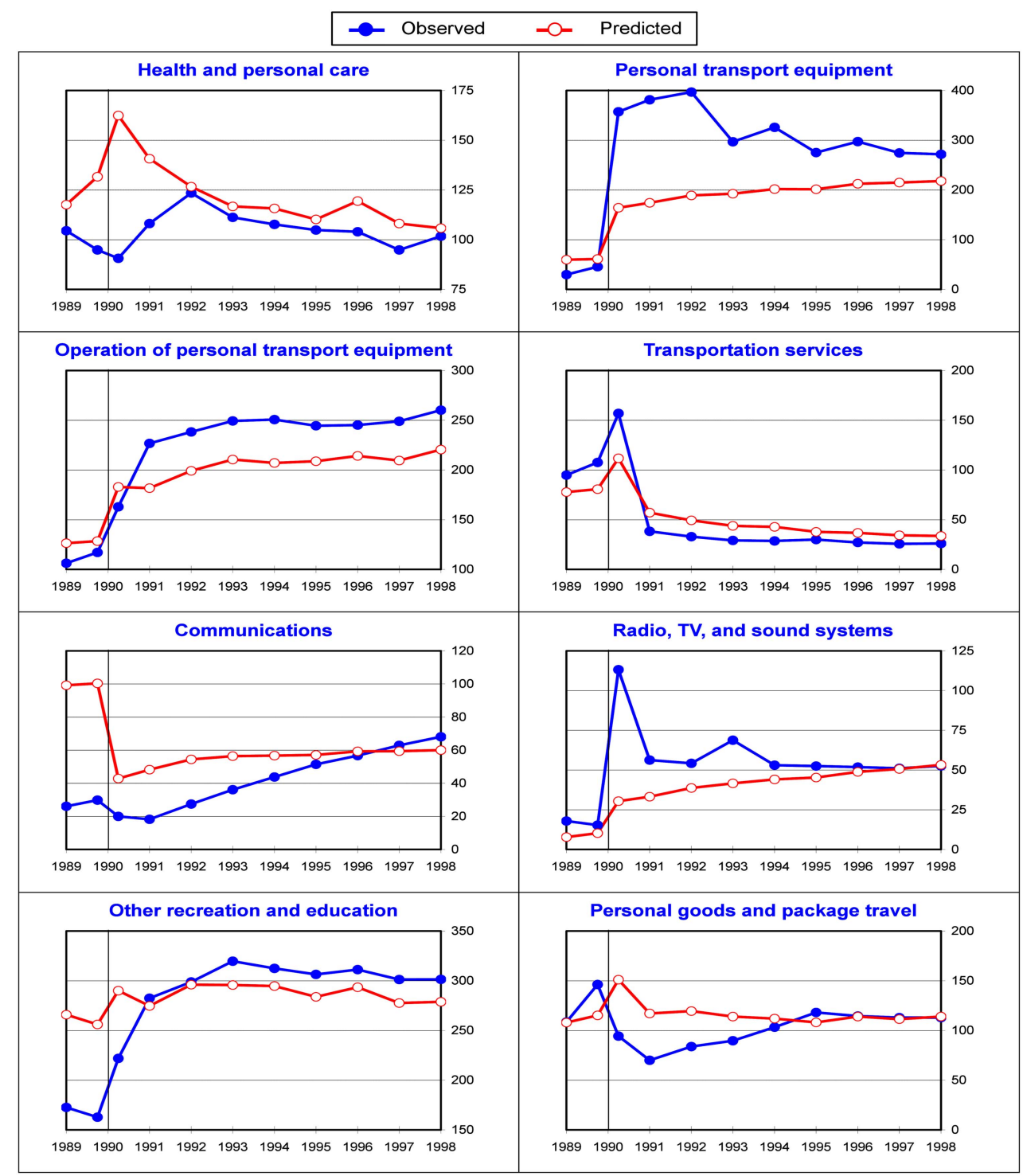


transition decade. There is a natural "goodness-of-fit" that reduces the sixteen individual deviations of forecast from observed demands to a single number, one rich with economic meaning and tradition, the concept of Hicksian compensating variation. $^{15}$

Figure 4a. Observed and predicted demands, Type 3 households, East Germany (DM per month, 1991 West German prices)

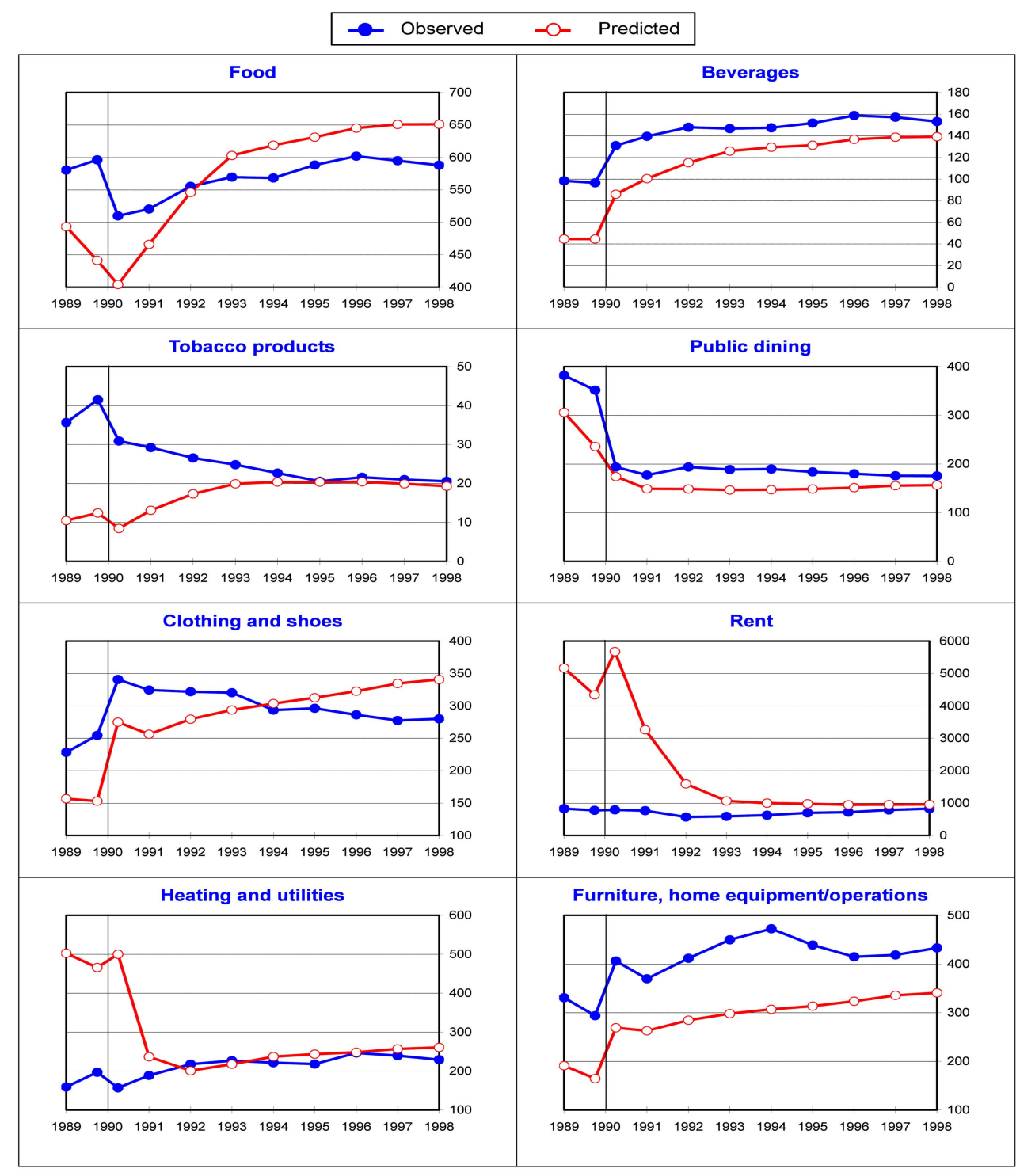

${ }^{15}$ Cf. Varian (1990). 
Figure 4b. Observed and predicted demands, Type 3 households, East Germany (DM per month, 1991 West German prices)

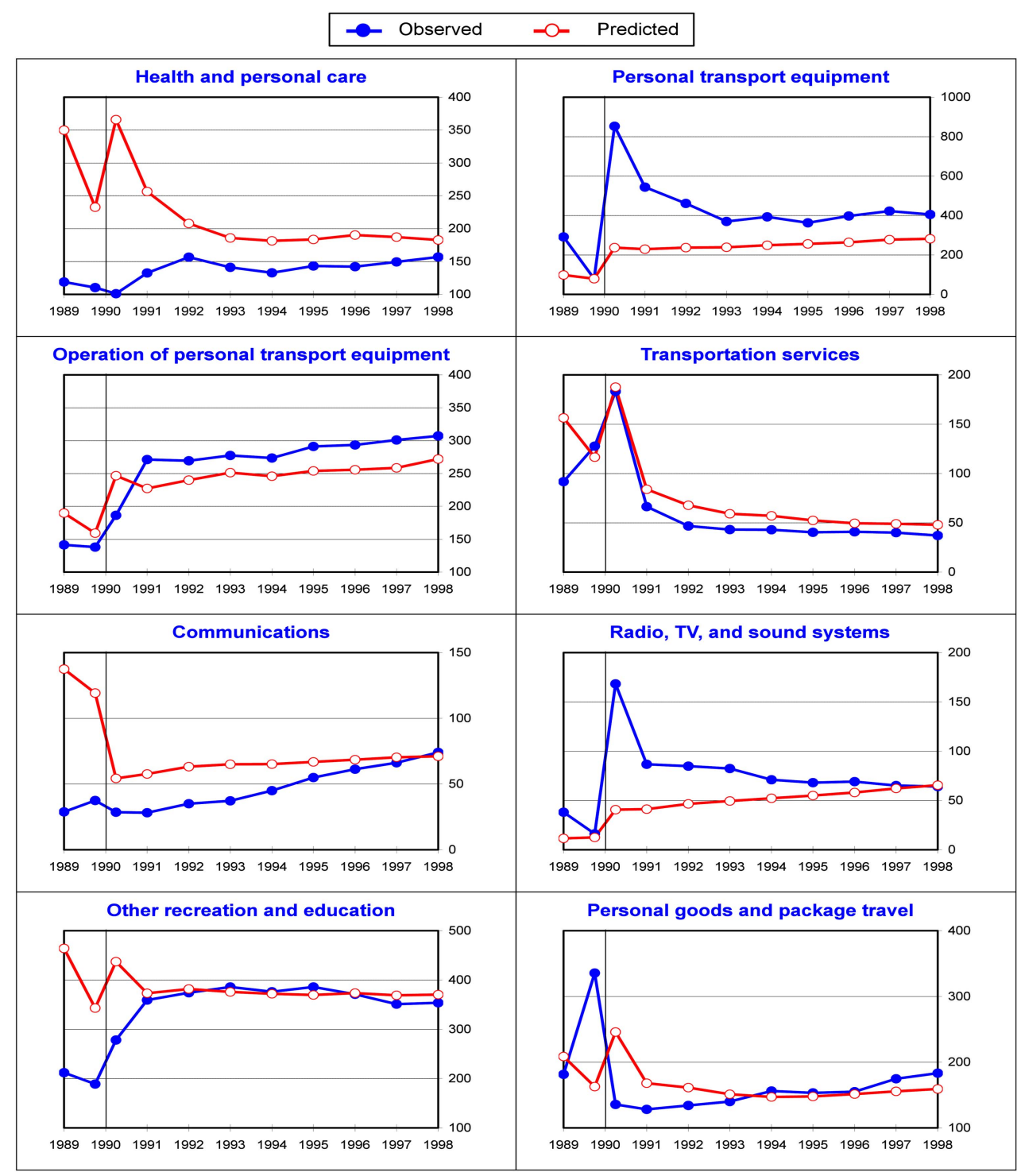

We first consider this measure in the context of the household under both quantity constraints as well as budget constraints, i.e., our pre-unification observations. An aggregate measure of the extent of the microeconomic disequilibrium experienced by a GDR household is the answer to the (compensating variation) question: 
"How much lower could the budget constraint have been for an average East German family in 1989 had it been free to buy at real existing GDR prices subject solely to its budget constraints, yet still maintaining its 1989 level of utility?"

When this answer is expressed as a percentage of the actual household budget, we have what I defined earlier as the "effective purchasing power gap," Collier (1986). The effective purchasing power gap expresses the household's willingness

Figure 5a. Effective purchasing power gaps for East German households 2 adults and 2 children.

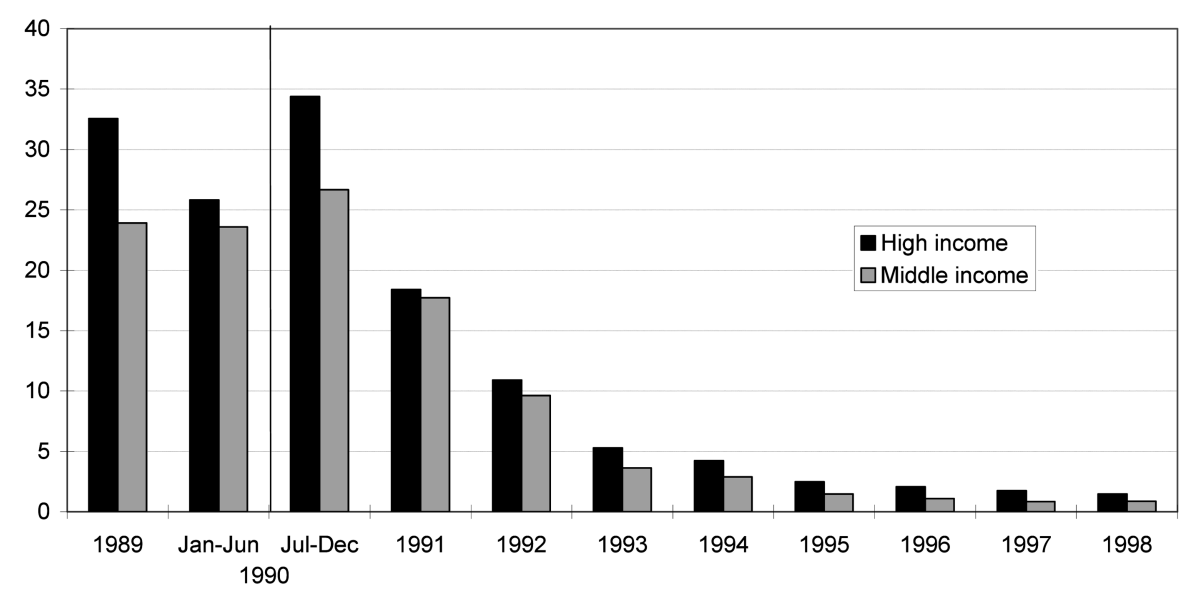

Figure 5b. Effective purchasing power gaps for East German households 2 elderly persons with income from pensions or social assistance.

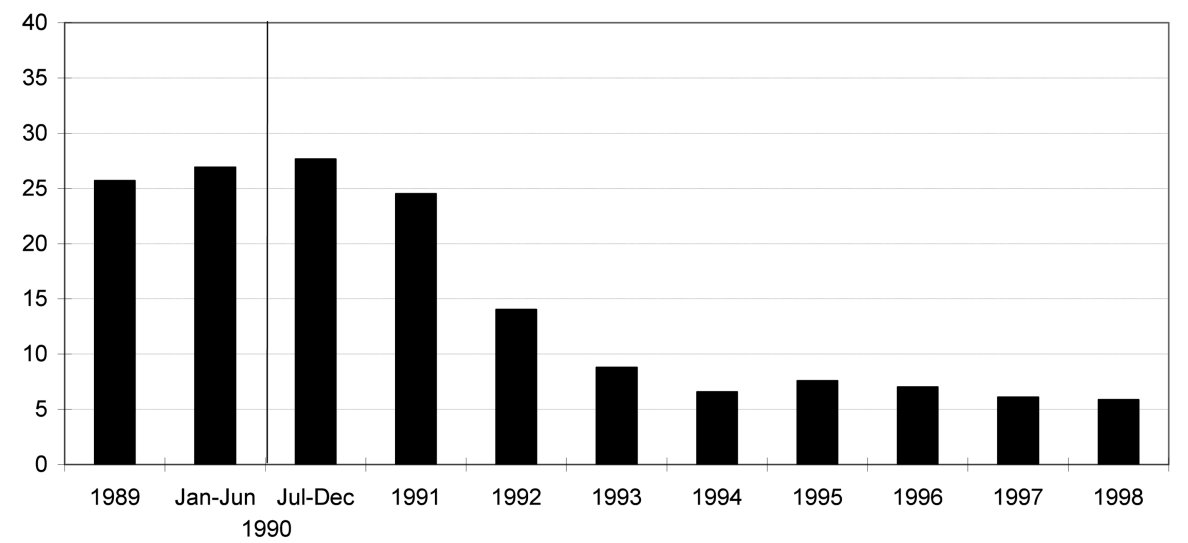


to pay for consumer sovereignty when they do not have it. ${ }^{16}$

This economic "goodness of fit" of the demand system estimated for West German households (the smaller the gap, the better the fit) reveals several important patterns (Figure 5). The first is the extent of quantity constraints under centrally planned socialism (1989 and the first half of 1990) along with their elimination over the course of transition. One can see that on average by 1993 the demand system gaps have fallen to well under five percent for middle income households in the East, meaning the parameters estimated using western budgets are beginning to do a pretty decent job of explaining the pattern of consumption spending in the new states. The second pattern that we see from Figure 5 is the clear differential impact of the shortages according to income levels. For working higher income households the effective purchasing power gap is estimated to have been on the order of one-third of total household consumption spending. For middle income working households and retired households the effective purchasing power gap is estimated to have been about a quarter of total household spending in $1989 .{ }^{17}$ The continued high value of the EPP gap requires a different interpretation for post July 1, 1990 East Germany. Rather than being solely a measure of quantity constraints, it begins to reflect the massive purchase of consumer durables at the start of economic unification (see Figures 2-4, e.g., for personal transport equipment) which a static model of demand by nature is going to miss. Nevertheless, the relatively slow price and quantity adjustment in the housing category still plays an important role and it takes the better part of a decade to work its way out (cf. Figures 2-4 for rent).

Together Table 2 and Figure 5 indicate the complexity of the task facing anyone attempting to construct deflators to extract real changes from the nominal economic data of East Germany in transition. There have been both an enormous change in relative prices together with the removal of significant quantity constraints. The impact of these changes are not proportional across the income distribution so that it becomes necessary to tailor the deflators for the decade of the 1990s in East Germany to the circumstances of households as well as we can.

\footnotetext{
${ }^{16}$ One need only recall that the humble banana as well as the (then) exotic Kiwi fruit became important symbols of German economic unification.

${ }^{17}$ When an analogous "EPP gap" is calculated for the West German households for this generalized CobbDouglas demand system, we obtain a figure consistently well below one percent of total spending.
} 


\section{Exact Deflators using Virtual Prices}

The previous discussion is necessary to help us build up the courage to take a great leap. A model of German preferences was built in West Germany using averages of a modest number of family budgets and then driven over a purchasing power parity bridge and lowered by a chain of price indexes to interpret family budgets of East Germany back in pre-unification days. Are the notional demands we predict reasonable when compared to the effective demands we observe? It is worth recalling: the model does indicate an enormous shortage of housing and likely spillover demand into food and beverages which coincides with common experience from the time. The effective purchasing power gaps do reflect that quantity constraints are a relatively greater concern for the nominally affluent compared to those with less income, also a fact that few if any would dispute. We also have seen that the model of German preferences does a much better job explaining the structure of East German family budgets as we move farther away from 1990, again a result that is consistent with what we might have expected and what we think we see.

To obtain an exact deflator, a number that we would divide into nominal spending of an East German household to compute the minimum DM sum required at some arbitrary set of prices (here 1991 West German prices), we need to have the level of utility $\left(v_{E}\right)$ for each East German observation. With it we can invert the indirect utility function to solve for the hypothetical expenditure $\left(\tilde{y}_{E}\right)$ at 1991 West German prices $\left(p_{W k}^{91}\right)$, where the budget shares are those associated with East German utility $\left(v_{E}\right)$ :

$$
\begin{aligned}
& \ln v_{E}=\ln \tilde{y}_{E}-\sum_{k} \beta_{E k} \ln p_{W k}^{91} \\
& \ln \tilde{y}_{E}=\ln v_{E}+\sum_{k} \beta_{E k} \ln p_{W k}^{91}
\end{aligned}
$$

Note that especially for the case of the early observations, $v_{E}$ should not simply be calculated by inserting East German prices and budgets into equation (2) because of the existence of quantity constraints. Were we to be working with the direct utility function, it would be simply a case of putting the observed East German market basket into the direct utility function to compute utility. However, the problem here is how can we legitimately use an indirect utility function where 
Table 4(a). Consumer prices (P), quantities (Q), and expenditures (X) 2-person, elderly East German households with pension/social assistance income in 1989

\begin{tabular}{|c|c|c|c|c|c|c|c|}
\hline & $\begin{array}{l}\text { Actual P } \\
\text { (1) }\end{array}$ & $\begin{array}{c}\text { Actual Q } \\
\text { (2) }\end{array}$ & $\begin{array}{c}\text { Actual X } \\
\text { (3) }\end{array}$ & $\begin{array}{c}\text { Notional Q } \\
\text { (4) }\end{array}$ & $\begin{array}{c}\text { Notional X } \\
\text { (5) }\end{array}$ & $\begin{array}{l}\text { Virtual P } \\
\text { (6) }\end{array}$ & $\begin{array}{l}\text { Virtual X } \\
\text { (7) }\end{array}$ \\
\hline Food & 0.73 & 399.93 & 292.14 & 177.69 & 129.80 & 0.56 & 223.62 \\
\hline Beverages & 1.94 & 66.13 & 128.15 & 14.40 & 27.89 & 0.68 & 44.65 \\
\hline Tobacco & 0.97 & 16.42 & 15.94 & 4.06 & 3.94 & 0.73 & 12.06 \\
\hline Public dining & 0.37 & 87.59 & 32.46 & 89.70 & 33.24 & 0.32 & 28.18 \\
\hline Clothing and footwear & 1.46 & 59.60 & 86.93 & 27.39 & 39.95 & 0.96 & 57.24 \\
\hline Rent & 0.11 & 475.58 & 51.94 & 2793.00 & 305.03 & 0.49 & 231.87 \\
\hline Fuel and power & 0.26 & 136.45 & 35.79 & 211.11 & 55.37 & 0.67 & 92.06 \\
\hline $\begin{array}{l}\text { Furn., household equip. } \\
\text { and operations }\end{array}$ & 1.17 & 105.42 & 123.85 & 44.12 & 51.84 & 0.63 & 66.91 \\
\hline Health and personal care & 0.52 & 74.71 & 38.75 & 103.67 & 53.77 & 0.60 & 44.66 \\
\hline $\begin{array}{l}\text { Personal transport } \\
\text { equipment }\end{array}$ & 2.05 & 2.68 & 5.50 & 43.86 & 89.87 & 3.46 & 9.29 \\
\hline $\begin{array}{l}\text { Operation of personal } \\
\text { transport equipment }\end{array}$ & 0.99 & 28.36 & 28.01 & 58.88 & 58.16 & 0.94 & 26.72 \\
\hline $\begin{array}{l}\text { Purchased transport } \\
\text { services }\end{array}$ & 0.25 & 86.55 & 21.70 & 30.64 & 7.68 & 0.21 & 18.26 \\
\hline Communications & 0.34 & 28.91 & 9.92 & 64.42 & 22.10 & 0.94 & 27.09 \\
\hline $\begin{array}{l}\text { Radio, television sets, pho- } \\
\text { nographs }\end{array}$ & 3.02 & 9.30 & 28.11 & 2.19 & 6.61 & 0.72 & 6.74 \\
\hline $\begin{array}{l}\text { Recreation, entertainment, } \\
\text { education, n.e.c. }\end{array}$ & 0.64 & 68.41 & 43.75 & 89.17 & 57.03 & 0.76 & 52.14 \\
\hline Personal effects, travel & 0.66 & 47.40 & 31.34 & 48.39 & 31.99 & 0.69 & 32.81 \\
\hline Total monthly expenditure & & & 974.29 & & 974.29 & $0.605^{*}$ & 974.29 \\
\hline
\end{tabular}

Cols. (1),(6): Prices expressed relative to West German prices in each category, 1991=1.00

Cols. (2), (4): Implicit quantities. $(2)=(3) /(1)$ and $(4)=(5) /(1)$

Col. (7): Actual quantities valued at virtual prices. $(7)=(2) \times(6)$

*Exact deflator to convert total expenditure into (west) DM prices of 1991.

quantity constraints interact with the budget constraint to determine choice sets? ${ }^{18}$ The answer is that we replace the East German prices with Rothbarthian virtual prices computed with the same model of demand. (See Table 4, column 6.) Actually, we need to simultaneously compute virtual prices along with the level of utility associated with observed East German consumption quantities. Given the virtual prices and the level of utility, we can then "throw away" the virtual prices and use $v_{E}$ to determine the $\beta_{E k}$, which along with $p_{W k}^{91}$ can be used to calculate $\tilde{y}_{E}$

\footnotetext{
${ }^{18}$ Actually this was an issue deliberately passed over when the effective purchasing power gaps were discussed in the last section. Now is expositionally a better time to address the issue.
} 
Table 4(b). Consumer prices (P), quantities (Q), and expenditures 2-adult, 2-children East German working households with middle incomes in 1989

\begin{tabular}{|c|c|c|c|c|c|c|c|}
\hline & $\begin{array}{l}\text { Actual P } \\
\text { (1) }\end{array}$ & $\begin{array}{l}\text { Actual Q } \\
\text { (2) }\end{array}$ & $\begin{array}{l}\text { Actual } X \\
\text { (3) }\end{array}$ & $\begin{array}{c}\text { Notional C } \\
\text { (4) }\end{array}$ & $\begin{array}{l}\text { Notional X } \\
\text { (5) }\end{array}$ & $\begin{array}{l}\text { Virtual P } \\
\text { (6) }\end{array}$ & $\begin{array}{l}\text { Virtual X } \\
\text { (7) }\end{array}$ \\
\hline Food & 0.73 & 563.96 & 411.96 & 414.17 & 302.54 & 0.62 & 347.66 \\
\hline Beverages & 1.94 & 85.45 & 165.58 & 36.00 & 69.76 & 0.92 & 78.24 \\
\hline Tobacco & 0.97 & 37.02 & 35.94 & 16.27 & 15.80 & 0.73 & 27.09 \\
\hline Public dining & 0.37 & 325.18 & 120.51 & 174.88 & 64.81 & 0.18 & 58.07 \\
\hline Clothing and footwear & 1.46 & 186.45 & 271.96 & 100.88 & 147.15 & 0.76 & 142.34 \\
\hline Rent & 0.11 & 758.06 & 82.79 & 3449.76 & 376.76 & 0.49 & 373.22 \\
\hline Fuel and power & 0.26 & 167.26 & 43.87 & 427.03 & 112.00 & 0.78 & 129.76 \\
\hline $\begin{array}{l}\text { Furn., household equip. } \\
\text { and operations }\end{array}$ & 1.17 & 204.45 & 240.19 & 123.82 & 145.46 & 0.69 & 141.38 \\
\hline Health and personal care & 0.52 & 104.50 & 54.20 & 117.60 & 60.99 & 0.37 & 38.69 \\
\hline $\begin{array}{l}\text { Personal transport } \\
\text { equipment }\end{array}$ & 2.05 & 29.51 & 60.47 & 59.77 & 122.47 & 3.86 & 113.97 \\
\hline $\begin{array}{l}\text { Operation of personal } \\
\text { transport equipment }\end{array}$ & 0.99 & 106.21 & 104.91 & 126.40 & 124.85 & 1.16 & 123.45 \\
\hline $\begin{array}{l}\text { Purchased transport } \\
\text { services }\end{array}$ & 0.25 & 94.85 & 23.78 & 77.79 & 19.50 & 0.17 & 15.95 \\
\hline Communications & 0.34 & 26.09 & 8.95 & 99.26 & 34.05 & 1.36 & 35.48 \\
\hline $\begin{array}{l}\text { Radio, television sets, } \\
\text { phonographs }\end{array}$ & 3.02 & 17.85 & 53.93 & 7.80 & 23.55 & 1.31 & 23.38 \\
\hline $\begin{array}{l}\text { Recreation, entertainment, } \\
\text { education, n.e.c. }\end{array}$ & 0.64 & 172.63 & 110.40 & 265.90 & 170.05 & 0.88 & 152.53 \\
\hline Personal effects, travel & 0.66 & 108.42 & 71.68 & 107.92 & 71.35 & 0.55 & 59.90 \\
\hline Total monthly expenditure & & & 1861.12 & & 1861.12 & $0.723^{*}$ & 1861.12 \\
\hline
\end{tabular}

Cols. (1),(6): Prices expressed relative to West German prices in each category, 1991=1.00

Cols. (2), (4): Implicit quantities. (2) $=(3) /(1)$ and $(4)=(5) /(1)$

Col. (7): Actual quantities valued at virtual prices. $(7)=(2) \times(6)$

*Exact deflator to convert total expenditure into (west) DM prices of 1991.

according to equation $\left(2^{\prime \prime}\right) .{ }^{19}$

More formally, the procedure for calculating the exact deflators is as follows:

1) Equation (5) is estimated using West German data to obtain estimates of the "all-German" preference parameters $\tilde{\alpha}$ and $\tilde{\gamma}$ for $K$-1 forecasting equations.

2) Virtual prices and $\ln (v)$, i.e., a total of $K+1$ unknowns, are calculated using the following $K+1$ equations:

a) the $K-1$ forecasting equations estimated in the previous step

\footnotetext{
${ }^{19}$ To compute the effective purchasing power gaps of the last section, East German prices, say $p_{E K}^{89}$, would have been used in this last step.
} 
Table 4(c). Consumer prices (P), quantities (Q), and expenditures $(\mathrm{X})$ 2-adult, 2-children East German working households with higher incomes in 1989

\begin{tabular}{|c|c|c|c|c|c|c|c|}
\hline & $\begin{array}{l}\text { Actual P } \\
\text { (1) }\end{array}$ & $\begin{array}{l}\text { Actual Q } \\
\text { (2) }\end{array}$ & $\begin{array}{l}\text { Actual X } \\
\text { (3) }\end{array}$ & $\begin{array}{l}\text { Notional Q } \\
\text { (4) }\end{array}$ & $\begin{array}{c}\text { Notional X } \\
\text { (5) }\end{array}$ & $\begin{array}{l}\text { Virtual P } \\
\text { (6) }\end{array}$ & $\begin{array}{l}\text { Virtual X } \\
\text { (7) }\end{array}$ \\
\hline$\overline{\text { Food }}$ & 0.73 & 580.59 & 424.11 & 493.42 & 360.43 & 0.78 & 455.00 \\
\hline Beverages & 1.94 & 98.32 & 190.51 & 44.53 & 86.28 & 1.07 & 105.21 \\
\hline Tobacco & 0.97 & 35.65 & 34.61 & 10.46 & 10.16 & 0.64 & 22.72 \\
\hline Public dining & 0.37 & 381.93 & 141.54 & 305.72 & 113.30 & 0.26 & 100.23 \\
\hline Clothing and footwear & 1.46 & 228.18 & 332.82 & 156.71 & 228.58 & 0.99 & 225.62 \\
\hline Rent & 0.11 & 827.83 & 90.41 & 5165.87 & 564.18 & 0.70 & 576.14 \\
\hline Fuel and power & 0.26 & 159.14 & 41.74 & 502.43 & 131.78 & 1.06 & 168.30 \\
\hline $\begin{array}{l}\text { Furn., household equip. } \\
\text { and operations }\end{array}$ & 1.17 & 330.65 & 388.44 & 190.94 & 224.32 & 0.67 & 222.92 \\
\hline $\begin{array}{l}\text { Health and personal } \\
\text { care }\end{array}$ & 0.52 & 118.81 & 61.62 & 349.90 & 181.48 & 0.83 & 98.05 \\
\hline $\begin{array}{l}\text { Personal transport } \\
\text { equipment }\end{array}$ & 2.05 & 291.32 & 596.93 & 98.55 & 201.93 & 0.65 & 188.60 \\
\hline $\begin{array}{l}\text { Operation of personal } \\
\text { transport equipment }\end{array}$ & 0.99 & 141.45 & 139.72 & 189.83 & 187.50 & 1.35 & 190.96 \\
\hline $\begin{array}{l}\text { Purchased transport } \\
\text { services }\end{array}$ & 0.25 & 91.78 & 23.01 & 156.45 & 39.23 & 0.33 & 30.47 \\
\hline Communications & 0.34 & 28.86 & 9.90 & 137.50 & 47.18 & 1.79 & 51.78 \\
\hline $\begin{array}{l}\text { Radio, television sets, } \\
\text { phonographs }\end{array}$ & 3.02 & 38.10 & 115.11 & 11.63 & 35.14 & 0.95 & 36.01 \\
\hline $\begin{array}{l}\text { Recreation, entertain- } \\
\text { ment, education, n.e.c. }\end{array}$ & 0.64 & 212.23 & 135.73 & 464.01 & 296.75 & 1.24 & 262.95 \\
\hline Personal effects, travel & 0.66 & 181.381 & 119.92 & 208.55 & 137.89 & 0.61 & 111.16 \\
\hline $\begin{array}{l}\text { Total monthly } \\
\text { expenditure }\end{array}$ & & & 2846.12 & & 2846.12 & 0.81 & 2846.12 \\
\hline
\end{tabular}

Cols. (1),(6): Prices expressed relative to West German prices in each category, 1991=1.00

Cols. (2),(4): Implicit quantities. (2) = (3)/(1) and (4) $=(5) /(1)$

Col. (7): Actual quantities valued at virtual prices. $(7)=(2) \mathrm{x}(6)$

b) the budget constraint (budget shares sum to unity), and

c) the indirect utility function (equation 2)

Note: Virtual prices are calculated from the estimated notional budget shares associated with the estimated level of indirect utility: $\hat{\beta}_{E k}=\hat{p}_{E k} q_{E k} / y_{E}$, where total eastern expenditure, $y_{E}$, and quantities for all $K$ expenditure groups are held constant at the observed values.

3) Using the level of East German utility calculated in the previous step, we can 
Table 5. Estimated deflators* and nominal monthly net income in East Germany by household type and year, 1989-98

\begin{tabular}{rcccccc}
\hline & $\begin{array}{c}\text { Elderly couple on pension } \\
\text { or social assistance }\end{array}$ & \multicolumn{2}{c}{$\begin{array}{c}2 \text { adults, } 2 \text { children } \\
\text { middle income }\end{array}$} & $\begin{array}{c}\text { 2 adults, } 2 \text { children } \\
\text { higher income }\end{array}$ \\
\cline { 2 - 7 } & Deflator & $\begin{array}{c}\text { Monthly net } \\
\text { income }\end{array}$ & Deflator & $\begin{array}{c}\text { Monthly } \\
\text { net income }\end{array}$ & Deflator & $\begin{array}{c}\text { Monthly } \\
\text { net income }\end{array}$ \\
\hline Jan-Jun 1989 & 0.605 & 1060 & 0.723 & 2407 & 0.814 & 3523 \\
Jul-Dec 1990 & 0.600 & 1087 & 0.711 & 2482 & 0.730 & 3865 \\
1991 & 0.636 & 1250 & 0.715 & 2692 & 0.800 & 3888 \\
1992 & 0.742 & 1780 & 0.809 & 3007 & 0.815 & 4017 \\
1993 & 0.986 & 2480 & 0.915 & 3465 & 0.927 & 4581 \\
1994 & 1.007 & 2550 & 0.968 & 3863 & 0.985 & 5080 \\
1995 & 1.047 & 2631 & 1.002 & 4087 & 1.016 & 5236 \\
1996 & 1.069 & 2720 & 1.021 & 4344 & 1.035 & 5625 \\
1997 & 1.084 & 2852 & 1.039 & 4422 & 1.054 & 5751 \\
1998 & 1.094 & 2925 & 1.050 & 4540 & 1.062 & 5921 \\
\hline
\end{tabular}

*Deflators can be divided into nominal monthly net incomes to obtain real monthly net incomes (valued at constant 1991 West German DM prices).

trivially calculate the DM expenditure total that would have been necessary to attain that level of utility at 1991 West German prices (trivial, since those prices are all normalized to unity anyway):

$$
\underbrace{\ln v_{E}}_{\substack{\text { calaulated } \\ \text { in step 2) }}}=\ln \tilde{y}_{E}-\sum_{k} \beta_{E k} \ln \underbrace{\ln p_{91 k}}_{=0}=\ln \tilde{y}_{E}
$$

4) The deflator is obtained by dividing the observed East German expenditure by the 1991-DM expenditure from the previous step. The deflator has the dimensionality of Eastern marks per DM (1991 prices). The deflators are gathered together for all three household types in Table 5.

For some purposes it is useful to stand the deflators in Table 5 on their heads and consider the purchasing power of money ${ }^{20}$ in the East compared to the West for

\footnotetext{
${ }^{20}$ Unfortunately, it is very easy to confuse deflators (factors that are divided into a nominal magnitude) with purchasing power parities (factors that multiply nominal magnitudes) in order to obtain real magnitudes. While the matter is merely one of multiplicative inverses, readers still need to watch their step.
} 
Figure 6. Purchasing power of one Mark (pre July 1990) or DM (post July 1990) in East Germany by household type (expressed in terms of DM at current West German prices)

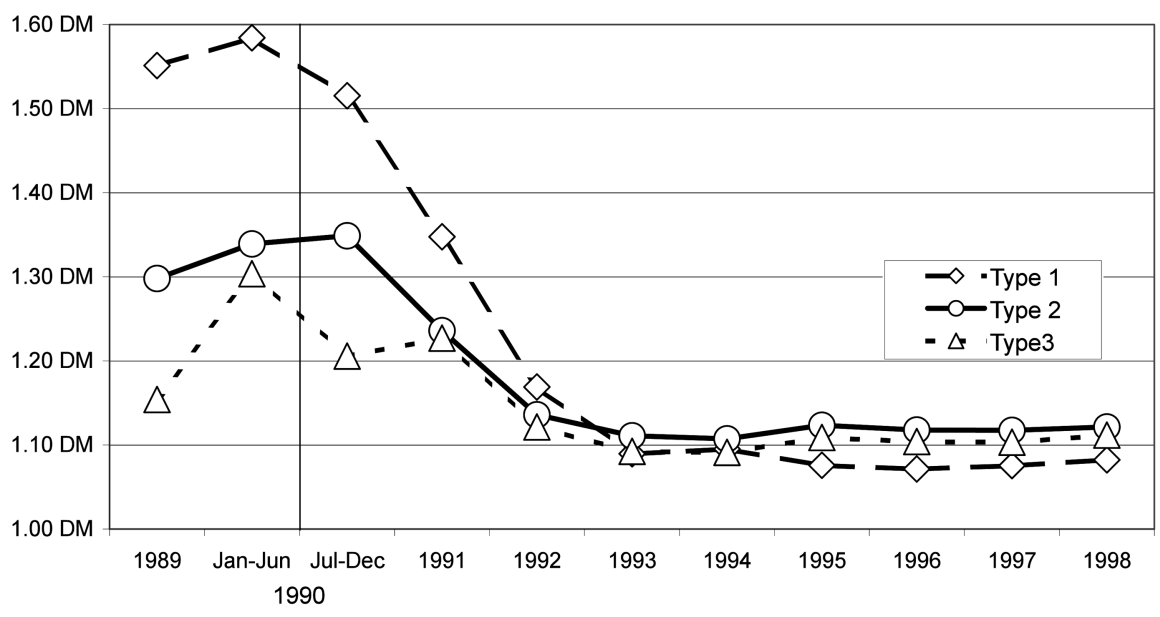

Type 1 household: 2 adult, elderly low income.

Type 2 household: 2 adults, 2 children. Middle income

Type 3 household: 2 adults, 2 children. Higher income

each year considered separately. This is done for the three different household types in Figure 6. We see that the purchasing power of the eastern German mark before economic and monetary unification with the West turns out to have been in fact greater than the DM for all three household types. The differential impact of the combined system of price subsidies and commodity taxes with quantity constraints across the income distribution in 1989 can be clearly seen. For the elderly couple living on a GDR old age pension, an Eastern mark bought on average what over one and a half DM in 1989 in West Germany would. The difference between middle and high income working households is clear for 1989 when the expectations of future systemic changes would not have played nearly the role that they did during the run up to monetary union in the first half of 1990. One sees for Type 3 households a drop in the purchases (postponement) of relatively big-ticket items (cf. Figure 4), the prices of which could have been expected to fall dramatically over the coming months. This sort of adjustment could have mattered more for the higher income families which might explain the upward blip of the purchasing power of the East mark for higher income families during the first half of 1990. Examination of Figure 6 reveals that most recently (1998) the new states 
have prices that are about one-tenth lower than in West Germany but that it is possible to speak of a single purchasing power parity for these household types rather than different purchasing power parities depending upon the household's circumstances.

\section{Conclusion}

While it remains something of a mystery why more has not been done to compare price levels between East and West Germany to help better assess the economic reconstruction of the new states of Germany, ${ }^{21}$ it is easy to appreciate why government statisticians have shied away from attempting to calculate deflators that would link present day East Germany to its pre-unification past. Indexes of relative purchasing power used in comparisons involving two very different economic systems must adjust for differences in the extent of non-price rationing (i.e., quantity constraints) as well as for differences in relative prices that reflect major differences in the indirect taxation/subsidization of consumer goods. The purpose of this paper has been to show that as long as the applied demand analyst is prepared to bring his or her own model of household preferences to these kinds of data, it is indeed feasible to obtain deflators that can span the change in economic system.

\section{Acknowledgement}

Support from the Volkswagen Foundation is gratefully acknowledged. Mr. G. Ströhl of the Federal Statistical Office graciously provided essential detailed IntraGerman price statistics. An earlier version of this paper was presented at the CEPR/ ECB workshop "Issues in the Measurement of Price Indices" held in Frankfurt, Germany in November, 2001.

Received 2 December 2011, Revised 2 April 2012, Accepted 18 May 2012

\footnotetext{
${ }^{21}$ Maybe not. Because of a lack of electronic storage capacity, the 1993 intragerman price comparisons are apparently no longer available in a machine readable form at the Federal Statistical Office. The underlying data could be made available to the author only as photocopies of computer output that had been kept by a conscientious government statistician.
} 


\section{References}

Beblo, Miriam, Irwin L. Collier, and Thomas Knaus (2012), The unification bonus (malus) of east Germans after the fall of the Berlin Wall, Journal of Economic Integration, 27(2), 222-244.

Collier, Irwin L. (1986), Effective purchasing power in a quantity constrained economy: An estimate for the German Democratic Republic, Review of Economics and Statistics 58(1), 24-32.

Collier, Irwin L. (1989), The measurement and interpretation of real consumption and purchasing power parity for a quantity constrained economy: The case of East and West Germany, Economica 56, 109-120.

Collier, Irwin L. (2005), "The 'Welfare Standard' and Soviet Consumers" in Paul R. Gregory and Marshall Goldman (eds.), Performance and Efficiency under Socialism: Studies in Honor of Abram Bergson. Comparative Economic Studies. 47, June, 333345.

Neary, J.P. and K.W.S. Roberts (1980), The theory of household behaviour under rationing. European Economic Review 13, 25.42.

Rothbarth, Erwin (1941), The measurement of changes in real income under conditions of rationing. Review of Economic Studies 8, 100-107.

Statistisches Bundesamt (1984-1998), Einnahmen und Ausgaben ausgewählter privater Haushalte. Fachserie 15. Reihe 1.

Statistisches Bundesamt (1984-1998), Preise und Preisindizes für die Lebenshaltung. Fachserie 17. Reihe 7, Preise und Preisindizes für die Lebenshaltung 1993.

Statistisches Bundesamt (1992a), Preise. Heft 32 Preisindex für die Lebenshaltung Mai 1990 bis April 1991 für das Gebiet der Länder Mecklenburg-Vorpommern, Brandenburg, Sachsen-Anhalt, Sachsen, Thüringen sowie Berlin (Ost).

Statistisches Bundesamt (1992b), Preise. Heft 59. Preisindex für die Lebenshaltung für das Gebiet der Länder Mecklenburg-Vorpommern, Brandenburg, Sachsen-Anhalt, Sachsen, Thüringen sowie Berlin (Ost). Juli 1990 bis Dezember 1991.

Statistisches Bundesamt (1993), Sonderreihe mit Beiträgen für das Gebiet der ehemaligen DDR. Heft 5. Einnahmen und Ausgaben privater Haushalte 1985 bis 1990.

Ströhl, G. (1994), Zwischenörtlicher Vergleich des Verbraucherpreisniveaus in 50 Städten. Wirtschaft und Statistik 94/6, 415-434.

Varian, Hal (1990), Goodness-of-fit in optimizing models. Journal of Econometrics, 46, $125-140$. 